medRxiv preprint doi: https://doi.org/10.1101/2020.03.10.20033795; this version posted March 16, 2020. The copyright holder for this preprint (which was not certified by peer review) is the author/funder, who has granted medRxiv a license to display the preprint in It is made available under a CC-BY-NC-ND 4.0 International license .

\title{
Active or latent tuberculosis increases susceptibility to COVID-19 and disease severity
}

Yu Chen, MD; Yaguo Wang, PhD; Joy Fleming, PhD; Yanhong Yu, MD; Ye Gu, MD; Chang Liu, MD; Lichao Fan, MD; Xiaodan Wang, BSN; Moxin Cheng, MD; Lijun Bi, PhD; Yongyu Liu, MD

\section{Author Affiliations:}

Department of Tuberculosis (Y. Chen, L. Fan), Tuberculosis Laboratory (Y. Yu), Department of Thoracic Surgery (C. Liu, Y. Liu), and Department of Respiration (X. Wang, M. Cheng), Shenyang Chest Hospital, Shenyang, Liaoning Province, 110044, P.R. China

Key Laboratory of RNA Biology and National Laboratory of Biomacromolecules, CAS Center for Excellence in Biomacromolecules, Institute of Biophysics, Chinese Academy of Sciences, Beijing 100101, China (Y. Wang, J. Fleming, L. Bi)

Shenyang Sixth People's Hospital, Shenyang, Liaoning Province, 110044, P.R. China (G. Ye)

\section{Corresponding authors:}

Yongyu Liu, MD, Department of Thoracic Surgery, Shenyang Chest Hospital, Shenyang, Liaoning Province 110044, China. (124315516@sina.com)

Lijun Bi, PhD, Institute of Biophysics, Chinese Academy of Sciences, Beijing 100101, China (blj@ibp.ac.cn)

\section{Key Points}

Question: Is latent or active tuberculosis (TB) a risk factor for SARS-CoV-19 infection and progression to severe COVID-19 pneumonia?

Findings: In this observational case-control study of 36 COVID-19 cases from Shenyang, China, we found tuberculosis history (both of active TB and latent TB) to be an important risk factor for NOTE: This preprint reports new research that has not been certified by peer review and should not be used to guide clinical practice. 
medRxiv preprint doi: https://doi.org/10.1101/2020.03.10.20033795; this version posted March 16, 2020. The copyright holder for this preprint (which was not certified by peer review) is the author/funder, who has granted medRxiv a license to display the preprint in It is made available under a CC-BY-NC-ND 4.0 International license .

SARS-CoV-2 infection. Patients with active or latent TB were more susceptible to SARS-CoV-2, and COVID-19 symptom development and progression were more rapid and severe.

Meaning: Tuberculosis status should be assessed carefully at patient admission and management and therapeutic strategies adjusted accordingly to prevent rapid development of severe COVID-19 complications.

\section{Abstract}

Importance: Risk factors associated with COVID-19, the viral pneumonia originating in Wuhan, China, in Dec 2019, require clarification so that medical resources can be prioritized for those at highest risk of severe COVID-19 complications. Infection with M. tuberculosis (MTB), the pathogen that causes TB and latently infects $\sim 25 \%$ of the global population, may be a risk factor for SARS-CoV-2 infection and severe COVID-19 pneumonia.

Objective: To determine if latent or active TB increase susceptibility to SARS-COV-19 infection and disease severity, and lead to more rapid development of COVID-19 pneumonia.

Design: An observational case-control study of 36 confirmed COVID-19 cases from Shenyang, China, conducted in Feb 2020. Final date of follow-up: Feb 29, 2020. Cases were grouped according to COVID-19 pneumonia severity (mild/moderate, severe/critical), and MTB infection status compared. Comparisons were made with MTB infection data from another case-control study on bacterial/viral pneumonia at Shenyang Chest Hospital.

Setting: Multi-center study involving three primary care hospitals in Shenyang, China.

Participants: 86 suspected COVID-19 cases from participating primary-care hospitals in Shenyang. All 36 SARS-CoV-2 +ve cases (based on RT-PCR assay) were included. Disease severity was assessed using the Diagnostic and Treatment Guidelines of the National Health Commission of China (v6). Mean age, 47 years (range: 25-79), gender ratio, 1:1. 
medRxiv preprint doi: https://doi.org/10.1101/2020.03.10.20033795; this version posted March 16, 2020. The copyright holder for this preprint (which was not certified by peer review) is the author/funder, who has granted medRxiv a license to display the preprint in It is made available under a CC-BY-NC-ND 4.0 International license .

Exposures: Confirmed COVID-19 pneumonia. Interferon-gamma Release Assays (IGRA) were performed using peripheral blood to determine MTB infection.

Main Outcome and Measures: Epidemiological, demographic, clinical, radiological, and laboratory data were collected. Comparison of MTB infection status between patients with mild/moderate and severe/critical COVID-19 pneumonia.

Results: Mean age of 36 COVID-19 patients: 47 (range: 25-79); M/F: 18/18; Wuhan/Hubei connection: 42\%. Mild/moderate cases: 27 (75\%); severe/critical: 9 (25\%). MTB infection (IGRA+ve): 13 cases (36.11\%), including 7 of 9 severe/critical cases. MTB infection rate: higher in COVID-19 (36.11\%) than bacterial pneumonia $(20 \% ; p=0.0047)$ and viral pneumonia patients (16.13\%; $\mathrm{p}=0.024)$. MTB infection more common than other co-morbidities $(36.11 \%$ vs diabetes: 25\%; hypertension: $22.2 \%$; coronary heart disease: $8.33 \%$; COPD: $5.56 \%$ ). MTB co-infection linked with disease severity (severe/critical $78 \%$ vs mild/moderate cases $22 \% ; \mathrm{p}=0.0049$ ), and rate of disease progression: infection to development of symptoms (MTB+SARS-CoV-2: $6.5 \pm 4.2$ days vs SARS-COV-2: 8.9 \pm 5.2 days; $\mathrm{p}=0.073$ ); from symptom development to diagnosed as severe (MTB+SARS-CoV-2: 3.4 \pm 2.0 days vs SARS-COV-2: $7.5 \pm 0.5$ days; $\mathrm{p}=0.075$ ).

Conclusions and Relevance: MTB infection likely increases susceptibility to SARS-CoV-2, and increases COVID-19 severity, but this requires validation in a larger study. MTB infection status of COVID-19 patients should be checked routinely at hospital admission.

\section{Introduction}

COVID-19, the viral pneumonia that emerged in Wuhan, China, in December 2019, has spread throughout China and to 85 other countries. To date (Mar 5, 2020), there have been 95,333 confirmed cases worldwide and 3282 deaths $^{1}$. COVID-19 poses a major threat to global health and was declared a 'public health emergency of international concern' by the WHO on 30 Jan $2020^{2}$. 
medRxiv preprint doi: https://doi.org/10.1101/2020.03.10.20033795; this version posted March 16, 2020. The copyright holder for this preprint (which was not certified by peer review) is the author/funder, who has granted medRxiv a license to display the preprint in It is made available under a CC-BY-NC-ND 4.0 International license .

While most SARS-CoV-2 infections in the general population result in only mild symptoms, individuals with underlying comorbidities, particularly the elderly, are more vulnerable to SARSCoV-2 infection and require additional care ${ }^{3-5}$. It is important to gain a clear picture of risk factors associated with this new viral respiratory infection in order to allocate appropriate medical resources to prevent the development of severe or critical forms of COVID-19 in those considered to be at higher risk. Here, we consider the possibility that infection with Mycobacterium tuberculosis, the pathogen that causes tuberculosis (TB), the top cause of death due to an infectious disease, may predispose to SARS-CoV infection and the more rapid development of symptoms and severe COVID-19 pneumonia.

\section{Methods}

Data collection

86 people with COVID-19 symptoms presented at hospitals in Shenyang, China, between Jan 26, 2020 and Feb 15, 2020 and were tested for SARS-CoV-2 infection. COVID-19 infection was confirmed in 36 cases (Shenyang Sixth People's Hospital [32 cases], Shenyang Fourth People's Hospital [4 cases] and Shenyang Chest Hospital [1 case]) and patients were hospitalized and enrolled in the study. Date of admission, gender, age, laboratory test results, and chest radiography results were extracted from patient admission records. The number of days from presumed contact with a suspected/confirmed COVID-19 patient to symptom development, the date on which SARSCoV-2 infection was confirmed, and disease severity were also recorded.

Data on MTB infection status were compared with retrospective data obtained from a caseseries study of 115 bacterial and 62 other viral pneumonia patients conducted in the Pulmonology Department of Shenyang Chest Hospital (unpublished data). All patients diagnosed with bacterial or viral pneumonia from Dec 20, 2019 to Feb 20, 2020 (cases in which SARS-CoV-2 infection/COVID-19 disease was ruled out according to criteria in the Diagnostic and Treatment 
medRxiv preprint doi: https://doi.org/10.1101/2020.03.10.20033795; this version posted March 16, 2020. The copyright holder for this preprint (which was not certified by peer review) is the author/funder, who has granted medRxiv a license to display the preprint in It is made available under a CC-BY-NC-ND 4.0 International license .

Guidelines of the National Health Commission of China (v5) ${ }^{9}$ ) were included in the study.

Demographic data are shown in Supplementary Table 1.

These studies were approved by the Ethics Committee of Shenyang Chest Hospital, and informed written consent was obtained from each of the study participants.

SARS-CoV-2 testing

Throat swabs, blood and sputum were collected from suspected COVID-19 patients and sent for SARS-CoV-2 testing using a real-time reverse-transcription polymerase chain reaction assay ${ }^{6,7}$ at the Shenyang Disease Control Center.

IFN- $\gamma$ IGRA assays

IFN- $\gamma$ IGRA assays were performed using X.DOT-TB kits (TB Healthcare, Foshan, China) according to the manufacturer's instructions ${ }^{8}$.

\section{Statistical analysis}

Analyses were performed using R (version 3.6.1). The normality of data distributions was assessed using the Kolmogorov-Smirnov test. Normally-distributed data are presented as means (SD), while non-normally distributed data are presented as medians (IQR), and categorical variables as frequencies (\%). Differences between groups were analysed by Fisher's exact test or Pearson's chisquared test (for categorical data), and Students' $t$-tests or Mann-Whitney tests (for continuous data).

\section{Results}

Among the 36 confirmed COVID-19 patients from Shenyang, Liaoning province, China, included in this study, the most common symptoms at presentation were cough $(61.11 \%)$, dyspnea $(33.33 \%)$, 
medRxiv preprint doi: https://doi.org/10.1101/2020.03.10.20033795; this version posted March 16, 2020. The copyright holder for this preprint (which was not certified by peer review) is the author/funder, who has granted medRxiv a license to display the preprint in It is made available under a CC-BY-NC-ND 4.0 International license .

fever $(27.78 \%)$, lymphopenia $(27.78 \%)$ and fatigue $(25 \%)$ (Table 1$)$. The mean age of patients was 47 years (range: $25-79$ ), and 18 were men. Fifteen cases had a connection with Wuhan/Hubei province or neighboring cities, while 21 had become infected via local transmission (3), or from friends/family members in Shenyang already diagnosed with COVID-19.

To evaluate the implications of MTB infection history on the incidence and progression of COVID-19 disease, we addressed three questions. Does MTB co-infection: 1. increase susceptibility to SARS-COV-19 infection; 2. increase disease severity; and 3. lead to more rapid disease progression? We first assigned cases into two groups based on the severity of their COVID19 pneumonia according to the Diagnostic and Treatment Guidelines of the National Health Commission of China (v6) ${ }^{9}$. Twenty-seven cases were mild/moderate (75\%, Group 1) and nine cases were severe/critical (25\%, Group 2) (Table 2). We then determined the MTB infection status of each patient by examining their clinical history and by performing X.DOT-TB IGRA assays (Table 1). Thirteen of the 36 COVID-19 cases (36.11\%) were IGRA+ve, of which 3 had active TB (1 MDR-TB), and 5 were recovered TB patients. Old TB calcifications were found on chest scans of 3 patients who had not previously been diagnosed with TB, and 2 patients had latent TB (LTBI). The percentage of IGRA+ve COVID-19 cases is approximately double the estimate of the percentage of IGRA+ve individuals in the general population $\left(15-18 \%\right.$ in rural China $\left.^{10}\right)$, suggesting that MTB infection likely is an important risk factor for susceptibility to SARS-COV-2 infection. To determine if MTB infection is a risk factor specific for COVID-19 pneumonia, or for pneumonia in general, we compared the MTB infection rate within these COVID-19 cases with data from a case-series comprised of 115 bacterial pneumonia and 62 viral pneumonia patients obtained from another study conducted in Shenyang (unpublished) (Figure 1A); MTB infection rates were considerably higher among COVID-19 patients than among bacterial pneumonia patients $(36.11 \%$ vs $20 \% ; p=0.047$ Figure $1 \mathrm{~A})$ and viral pneumonia patients $(36.11 \%$ vs $16.13 \% ; p=0.024)$, suggesting that MTB infection status is a specific risk factor for SARS-COV-2 infection rather than for pneumonia in general. The rate of MTB infection in the bacterial and other viral pneumonia 
medRxiv preprint doi: https://doi.org/10.1101/2020.03.10.20033795; this version posted March 16, 2020. The copyright holder for this preprint (which was not certified by peer review) is the author/funder, who has granted medRxiv a license to display the preprint in It is made available under a CC-BY-NC-ND 4.0 International license .

patients was not significantly different and was approximately the same as that in the general population $^{10}$. The percentage of patients with MTB infection was also considerably higher than the percentage of patients with other co-morbidities (diabetes: $25 \%$; hypertension: $22.2 \%$; coronary heart disease: $8.33 \%$; COPD: 5.56\%; Table 1), suggesting MTB infection represents a higher risk for SARS-CoV-2 infection.

With respect to disease severity, the percentage of severe/critical cases with MTB coinfection was significantly higher than that in the mild/moderate group ( $78 \%$ vs $22 \%$; $=0.0049$; Figure 1B). Seven of the 9 severe/critical cases were IGRA+ve indicating MTB co-infection, and of these, 4 of the 5 cases that developed ARDS were IGRA+ve. By comparison, 21 of 27 cases (78\%) in Group 1 (mild/moderate cases) were IGRA-ve and had no history of TB disease. This data infers that coinfection of SARS-CoV-2 with MTB tends to lead to the development of more severe or critical COVID-19 symptoms.

Our data also show that MTB infection is associated with more rapid development of symptoms (Figure 1C-D); MTB coinfected COVID-19 cases developed symptoms on average 3.3 days earlier than their non-MTB-infected counterparts. Development of critical symptoms is reported to occur on average 9 days after initial symptom onset ${ }^{4}$. The 7 MTB-infected severe/critical COVID-19 cases here, however, were categorized as severe/critical 3.4 days after initial symptom development. While the number of cases here is not sufficient to draw a solid conclusion, it would appear that COVID-19 disease progresses more rapidly in the presence of MTB coinfection.

\section{Discussion}

This observational study of the relationship between MTB infection and COVID-19 pneumonia suggests that individuals with latent or active TB may be more susceptible to SARS-CoV-2 infection, and that COVID-19 disease progression may be more rapid and severe. Given that TB causes more deaths than any other infectious disease (1.45 million deaths and 10 million new cases 
medRxiv preprint doi: https://doi.org/10.1101/2020.03.10.20033795; this version posted March 16, 2020. The copyright holder for this preprint (which was not certified by peer review) is the author/funder, who has granted medRxiv a license to display the preprint in It is made available under a CC-BY-NC-ND 4.0 International license .

in $2018^{11}$ ), and that global rates of LTBI are estimated to be as high as $25 \%{ }^{11}$, these findings are a cautionary reminder to clinicians that MTB infection status should be considered when treating COVID-19 patients in order to prevent rapid deterioration in patient health.

Our data suggest that MTB infection could be a more important risk factor than the comorbidities commonly reported in epidemiological studies such as diabetes and hypertension ${ }^{12}$. COVID-19 and TB are both respiratory diseases. It is perhaps not surprising that chronic respiratory diseases such as Chronic Obstructive Pulmonary Disease (COPD), and indeed active TB, could predispose susceptibility to SARS-CoV-2. Statistics from other reported studies, however, suggest that the frequency of these co-morbidities is much lower than that of MTB infection in this study (COPD: $1 \%$ of 1099 COVID-19 cases $^{12}$, chronic respiratory disease: $2.4 \%$ of 72,314 COVID-19 $\operatorname{cases}^{13}$ ). The strength of this finding, however, is limited by the relatively low number of cases involved in this study and requires further validation.

Based on our findings, we make the following recommendations for the management and treatment of patients with a history of MTB infection (LTBI or active TB) and possible SARSCoV-2 coinfection. First, the medical and wider community should be informed that latent/active TB is a risk factor for SARS-CoV-2 infection, and those at risk should be encouraged to pay special attention to preventive measures. Ideally, this vulnerable group should be monitored regularly at community-based medical centers in situations when resources are available. Second, the MTB infection status (history and IGRA response) of suspected/confirmed COVID-19 cases should be checked routinely on admission to ensure coinfected cases are placed in appropriate isolation wards if active TB is detected. Third, special medical resources (such as ECMO therapy) should be arranged in advance for coinfected patients in view of the increased likelihood of rapid development of severe or critical symptoms. Fourth, therapeutic approaches for cases known to be coinfected both SARS-CoV-2 and MTB should bear their MTB infection history in mind; for example, treatments involving immunosuppressive agents should be reconsidered, as they hold the potential to reactivate latent TB infections. 
medRxiv preprint doi: https://doi.org/10.1101/2020.03.10.20033795; this version posted March 16, 2020. The copyright holder for this preprint (which was not certified by peer review) is the author/funder, who has granted medRxiv a license to display the preprint in It is made available under a CC-BY-NC-ND 4.0 International license .

This is the first study to date to consider MTB infection as a comorbidity for COVID-19. Going forward, it will be important to validate the relationship uncovered here among these 36 COVID-19 cases in a larger study.

\section{Acknowledgments}

We would like to thank all healthcare professionals involved in the treatment and management of the COVID-19 patients in this study for their dedication and commitment. We would like to acknowledge Dr Juanjuan Zhang, MD (Shenyang Fourth People's Hospital) for coordinating the four COVID-19 cases in the cohort from Shenyang Fourth People's Hospital. We also thank BCBIO Biotechnology (Guangdong, China) for help with data analysis.

\section{Funding/Support}

Funding for this work was from the Shenyang Major Science and Technology Innovation R\&D Program (JY2020-9-018 to Y. Chen), and the National Science and Technology Major Projects (2018ZX10731301-003, 2018ZX10731301-009 and 2018ZX10731301-010 to L. Bi).

\section{Role of the Funder/Sponsor:}

The funders had no role in the design and conduct of the study; collection, management, analysis, and interpretation of the data; preparation, review, or approval of the manuscript; and decision to submit the manuscript for publication.

\section{Conflict of Interest Disclosures:}

The authors declare no conflicts of interest. 
medRxiv preprint doi: https://doi.org/10.1101/2020.03.10.20033795; this version posted March 16, 2020. The copyright holder for this preprint (which was not certified by peer review) is the author/funder, who has granted medRxiv a license to display the preprint in It is made available under a CC-BY-NC-ND 4.0 International license .

\section{Author Contributions:}

Y. Chen, Y. Wang, J. Fleming, L. Bi and Y. Liu had full access to all of the data in the study and take responsibility for the integrity of the data and the accuracy of the data analysis. Y. Chen, Y. Wang and J. Fleming contributed equally and share first authorship.

Concept and design: Y. Chen, Y. Wang, J. Fleming, L. Bi and Y. Liu Acquisition, analysis, or interpretation of data: Y. Chen, Y. Wang, J. Fleming, Y. Yu, C. Liu, L.

Fan, X. Wang, M. Cheng

Drafting of the manuscript: J. Fleming, Y. Wang

Critical revision of the manuscript for important intellectual content: Y. Chen, Y. Wang, J.

Fleming, L. Bi and Y. Liu

Statistical analysis: Y. Wang

Obtained funding: Y. Chen, L. Bi

Administrative, technical, or material support: Y. Chen, Y. Yu, C. Liu, L. Fan, X. Wang, M. Cheng Supervision: Y. Gu, L. Bi, Y. Liu

\section{References}

1. Coronavirus disease 2019 (COVID-19) Situation Report -45.

https://www.who.int/docs/default-source/coronaviruse/situation-reports/20200305-sitrep-45covid-19.pdf?sfvrsn=ed2ba78b_2

2. Coronavirus disease 2019 (COV̄ID-19) Situation Report - 10. https://www.who.int/docs/default-source/coronaviruse/situation-reports/20200130-sitrep-10ncov.pdf?sfvrsn=d0b2e480_2

3. Zhang JJ, Dong X, Cao YY, et al. Clinical characteristics of 140 patients infected with SARS-CoV-2 in Wuhan, China. Allergy. Feb 19 2020. doi:10.1111/all.14238.

4. Huang C, Wang Y, Li X, et al. Clinical features of patients infected with 2019 novel coronavirus in Wuhan, China. Lancet Feb 15 2020;395(10223):497-506.

5. $\mathrm{Wu} \mathrm{Z}, \mathrm{McGoogan} \mathrm{JM}$. Characteristics of and Important Lessons From the Coronavirus Disease 2019 (COVID-19) Outbreak in China: Summary of a Report of 72314 Cases From the Chinese Center for Disease Control and Prevention. JAMA. Feb 242020. doi:10.1001/jama.2020.2648.

6. Lan L, Xu D, Ye G, et al. Positive RT-PCR Test Results in Patients Recovered From COVID-19. JAMA. Feb 27 2020. doi:10.1001/jama.2020.2783.

7. Wang D, Hu B, Hu C, et al. Clinical Characteristics of 138 Hospitalized Patients With 2019 Novel Coronavirus-Infected Pneumonia in Wuhan, China. JAMA. Feb 7 2020.doi:10.1001/jama.2020.1585. 
medRxiv preprint doi: https://doi.org/10.1101/2020.03.10.20033795; this version posted March 16, 2020. The copyright holder for this preprint (which was not certified by peer review) is the author/funder, who has granted medRxiv a license to display the preprint in It is made available under a CC-BY-NC-ND 4.0 International license .

8. Ewer K, Deeks J, Alvarez L, et al. Comparison of T-cell-based assay with tuberculin skin test for diagnosis of Mycobacterium tuberculosis infection in a school tuberculosis outbreak. The Lancet. 2003;361(9364):1168-1173.

9. Handbook of Prevention and Treatment of the Pneumonia Caused by the Novel Coronavirus. (2019-nCoV). http://en.nhc.gov.cn/2020-02/06/c_76295.htm

10. Gao L, Lu W, Bai L, et al. Latent tuberculosis infection in rural China: baseline results of a population-based, multicentre, prospective cohort study. The Lancet. Infectious diseases. Mar 2015;15(3):310-319.

11. WHO. Global Tuberculosis Report 2019.

12. Guan WJ, Ni ZY, Hu Y, et al. Clinical Characteristics of Coronavirus Disease 2019 in China. The New England Journal of Medicine. Feb 28 2020. doi:10.1056/NEJMoa2002032.

13. The Novel Coronavirus Pneumonia Emergency Response Epidemiology Team. Epidemiological Characteristics of an Outbreak of 2019 Novel Coronavirus Diseases (COVID-19) — China, 2020 2020, 2(8): 113-122. 
medRxiv preprint doi: https://doi.org/10.1101/2020.03.10.20033795; this version posted March 16, 2020. The copyright holder for this preprint (which was not certified by peer review) is the author/funder, who has granted medRxiv a license to display the preprint in It is made available under a CC-BY-NC-ND 4.0 International license.

Tables and Figures

Table 1. Comorbidities present in COVID-19 patients

\begin{tabular}{|c|c|c|c|c|}
\hline Comorbidities & $\begin{array}{l}\text { All patients } \\
\qquad(\mathrm{n}=36)\end{array}$ & $\begin{array}{l}\text { Mild/Moderate } \\
\qquad(\mathrm{n}=27)\end{array}$ & $\begin{array}{c}\text { Severe/Critical } \\
\quad(n=9)\end{array}$ & $\begin{array}{c}p \text { value* } \\
\text { (Fisher's exact } \\
\text { test) }\end{array}$ \\
\hline Tuberculosis (TB) & .. & .. & .. & 0.0049 \\
\hline ELISPOT positive & $13(36.11 \%)$ & $6(22.22 \%)$ & $7(77.78 \%)$ &.. \\
\hline old TB calcifications & 3 & 2 & 1 & .. \\
\hline TB history & 5 & 2 & 3 & .. \\
\hline active TB & 3 & 0 & 3 & .. \\
\hline LTBI & 2 & 2 & 0 & .. \\
\hline ELISPOT negative & $23(63.89 \%)$ & $21(77.78 \%)$ & $2(22.22 \%)$ & .. \\
\hline $\begin{array}{l}\text { Chronic obstructive } \\
\text { pulmonary disease } \\
\text { (COPD) }\end{array}$ & .. & .. & .. & 0.0571 \\
\hline positive & $2(5.56 \%)$ & $0(0)$ & $2(22.22 \%)$ & .. \\
\hline negative & $34(94.44 \%)$ & $27(100 \%)$ & $7(77.78 \%)$ & .. \\
\hline Diabetes & .. & .. &.. & 0.738 \\
\hline positive & $9(25.00 \%)$ & $7(25.93 \%)$ & $2(22.22 \%)$ & .. \\
\hline negative & $27(75 \%)$ & $20(74.07 \%)$ & $7(77.78 \%)$ & .. \\
\hline Hypertension & .. & .. & .. & 0.6478 \\
\hline positive & $8(22.22 \%)$ & $7(25.93 \%)$ & $1(11.11 \%)$ &.. \\
\hline negative & $28(77.78 \%)$ & $20(74.07 \%)$ & $8(88.89 \%)$ & .. \\
\hline Coronary heart disease & .. & .. &.. & 1 \\
\hline positive & $3(8.33 \%)$ & $2(7.40 \%)$ & $1(11.11 \%)$ &.. \\
\hline negative & $33(91.67 \%)$ & $25(92.60 \%)$ & $8(88.89 \%)$ &.. \\
\hline Cerebrovascular diseases & 0 & 0 & 0 & .. \\
\hline Hepatitis B infection & .. & .. & .. & 0.25 \\
\hline positive & $1(2.78 \%)$ & $1(3.7 \%)$ & $0(0 \%)$ & .. \\
\hline negative & $35(97.22 \%)$ & $26(96.3 \%)$ & $9(100 \%)$ &.. \\
\hline Cancer & 0 & 0 & 0 & .. \\
\hline Chronic renal diseases & 0 & 0 & 0 &.. \\
\hline Immunodeficiency & .. & .. & .. & 0.25 \\
\hline positive & $1(2.78 \%)$ & $1(3.70 \%)$ & $0(0 \%)$ &.. \\
\hline negative & $35(97.22 \%)$ & $26(92.30 \%)$ & $9(100 \%)$ & .. \\
\hline
\end{tabular}

Data presented: $\mathrm{n}(\%) .{ }^{*}$ Significance of differences between the Mild/Moderate and Severe/Critical groups. 
medRxiv preprint doi: https://doi.org/10.1101/2020.03.10.20033795; this version posted March 16, 2020. The copyright holder for this preprint (which was not certified by peer review) is the author/funder, who has granted medRxiv a license to display the preprint in It is made available under a CC-BY-NC-ND 4.0 International license .

Table 2. Clinical characteristics and laboratory results for 36 COVID-19 cases

\begin{tabular}{|c|c|c|c|c|}
\hline Clinical Characteristics & $\begin{array}{l}\text { All cases } \\
(\mathrm{n}=\mathbf{3 6})\end{array}$ & $\begin{array}{l}\text { Mild/Moderate } \\
\quad(\mathbf{n}=\mathbf{2 7})\end{array}$ & $\begin{array}{l}\text { Severe/Critical } \\
\quad(\mathrm{n}=9)\end{array}$ & $p$-value* \\
\hline Age (years) & $47 \pm 14$ & $48 \pm 15$ & $56 \pm 11$ & 0.8856 \\
\hline Gender (M/F) & $18 / 18$ & $16 / 11$ & $7 / 2$ & 0.4377 \\
\hline Fever & $23(63.89 \%)$ & $16(59.26 \%)$ & $7(77.78 \%)$ & 0.4377 \\
\hline $\begin{array}{l}\text { Highest temperature during } \\
\text { hospital admission }\end{array}$ & $37.7 \pm 0.99$ & $37.6 \pm 1.03$ & $37.9 \pm 0.89$ & 0.5091 \\
\hline Conjunctival congestion & $3(8.33 \%)$ & $1(3.70 \%)$ & $2(22.22 \%)$ & 0.1866 \\
\hline Nasal congestion & $5(13.89 \%)$ & $5(18.52 \%)$ & 0 & 0.4908 \\
\hline Headache & $2(5.56 \%)$ & $2(7.41 \%)$ & 0 & 1 \\
\hline Cough & $22(61.11 \%)$ & $18(66.67 \%)$ & $4(44.44 \%)$ & 0.7797 \\
\hline Sore throat & $7(1.44 \%)$ & $5(18.52 \%)$ & $2(22.22 \%)$ & 0.7832 \\
\hline Sputum production & $8(22.22 \%)$ & $6(22.22 \%)$ & $2(22.22 \%)$ & 0.6517 \\
\hline Fatigue & $9(25 \%)$ & $5(18.52 \%)$ & $4(44.44 \%)$ & 0.4593 \\
\hline Hemoptysis & $2(5.56 \%)$ & 0 & $2(22.22 \%)$ & 0.0782 \\
\hline Dyspnea & $12(33.33 \%)$ & $4(14.81 \%)$ & $8(88.89 \%)$ & 0.0235 \\
\hline Nausea or vomiting & $5(13.89 \%)$ & $3(11.11 \%)$ & $2(22.22 \%)$ & 0.8644 \\
\hline Diarrhea & $7(19.44 \%)$ & $5(18.52 \%)$ & $2(22.22 \%)$ & 0.7832 \\
\hline Myalgia or arthralgia & $6(16.67 \%)$ & $3(11.11 \%)$ & $3(33.33 \%)$ & 0.4431 \\
\hline Chills & $5(13.89 \%)$ & $4(14.81 \%)$ & $1(11.11 \%)$ & 0.7752 \\
\hline Laboratory Tests & $\begin{array}{l}\text { All cases } \\
(n=36)\end{array}$ & $\begin{array}{l}\text { Mild/Moderate } \\
\quad(n=27)\end{array}$ & $\begin{array}{l}\text { Severe/Critical } \\
\quad(n=9)\end{array}$ & $p$-value* \\
\hline $\begin{array}{l}\text { Blood leukocyte count } \\
\left(3.5-9.5 \times 10^{\wedge} 9 / \mathrm{L}\right)\end{array}$ & $6.384 \pm 3.548$ & $5.928 \pm 2.602$ & $8.433 \pm 5.671$ & 0.0831 \\
\hline $\begin{array}{l}\text { Lymphocyte count } \\
\left(1.1-3.2 \times 10^{\wedge} 9 / \mathrm{L}\right)\end{array}$ & $1.657 \pm 1.115$ & $1.861 \pm 1.037$ & $0.738 \pm 0.477$ & 0.0164 \\
\hline Lymphopenia & $10(27.78 \%)$ & $5(18.52 \%)$ & $5(55.56 \%)$ & 0.0794 \\
\hline $\begin{array}{l}\text { Platelet count } \\
\left(125-350 \times 10^{\wedge} 9 / \mathrm{L}\right)\end{array}$ & $220.75 \pm 107.077$ & $\begin{array}{c}216.519 \pm 110.59 \\
7\end{array}$ & $\begin{array}{c}233.444 \pm 92.93 \\
7\end{array}$ & 0.6875 \\
\hline $\begin{array}{l}\text { Haemoglobin level } \\
(115-150 \mathrm{~g} / \mathrm{L})\end{array}$ & $140(20)$ & $139.6154(19)$ & $140(19)$ & 0.6519 \\
\hline $\begin{array}{l}\text { C-reactive protein level } \\
(0-4 \mathrm{mg} / \mathrm{L})\end{array}$ & $5.36(27.14)$ & $4.47(10.37)$ & $35.88(95.59)$ & 0.002 \\
\hline $\begin{array}{l}\text { Procalcitonin level } \\
(0.02-0.05 \mathrm{ng} / \mathrm{mL})\end{array}$ & $0.04(0.0125)$ & $0.04(0.01)$ & $0.05(0.05)$ & 0.037 \\
\hline $\begin{array}{l}\text { Lactose dehydrogenase } \\
(120-250 \mathrm{U} / \mathrm{L})\end{array}$ & $\begin{array}{c}466.429 \pm 160.61 \\
3\end{array}$ & $\begin{array}{c}455.846 \pm 143.87 \\
0\end{array}$ & $497 \pm 200.486$ & 0.4638 \\
\hline $\begin{array}{l}\text { Aspartate aminotransferase } \\
(13-35 \mathrm{U} / \mathrm{L})\end{array}$ & $26.743 \pm 15.483$ & $23.692 \pm 12.562$ & $35.556 \pm 19.475$ & 0.0395 \\
\hline $\begin{array}{l}\text { Alanine aminotransferase } \\
(7-40 \mathrm{U} / \mathrm{L})\end{array}$ & $32.657 \pm 22.357$ & $26.385 \pm 17.613$ & $50.778 \pm 24.432$ & 0.0027 \\
\hline $\begin{array}{l}\text { Total bilirubin } \\
(3.42-20.52 \mu \mathrm{mol} / \mathrm{L})\end{array}$ & $19.906 \pm 8.892$ & $19.462 \pm 7.368$ & $21.834 \pm 12.167$ & 0.438 \\
\hline
\end{tabular}


medRxiv preprint doi: https://doi.org/10.1101/2020.03.10.20033795; this version posted March 16, 2020. The copyright holder for this preprint (which was not certified by peer review) is the author/funder, who has granted medRxiv a license to display the preprint in It is made available under a CC-BY-NC-ND 4.0 International license.

\begin{tabular}{lcccc} 
Creatinine kinase $(40-$ & $40(27)$ & $39.5(23)$ & $59(86)$ & 0.104 \\
200U/L) & $51.706 \pm 20.446$ & $51.038 \pm 15.334$ & $54.6 \pm 29.976$ & 0.5495 \\
Creatinine $(41-73 \mu \mathrm{mol} / \mathrm{L})$ & $132.771 \pm 22.371$ & $133.154 \pm 25.374$ & $131.667 \pm 3.082$ & 0.2549 \\
Sodium $(137-147 \mathrm{mmol} / \mathrm{L})$ & $4.312 \pm 1.457$ & $4.327 \pm 0.972$ & $4.25 \pm 2.145$ & 0.7467 \\
\hline Potassium $(3.5-5.3 \mathrm{mmol} / \mathrm{L})$ & $97.8 \pm 16.846$ & $97.846 \pm 18.775$ & $97.66 \pm 6.595$ & 0.9163 \\
\hline Chloride $(99-110 \mathrm{mmol} / \mathrm{L})$ & 97.5 \\
\hline
\end{tabular}

Data: mean \pm SD or $n(\%)$. *Difference between mild/moderate and severe/critical groups.

\section{Figures}

A

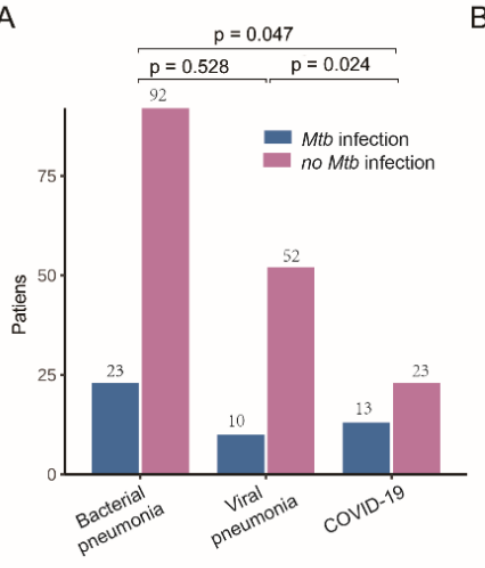

B

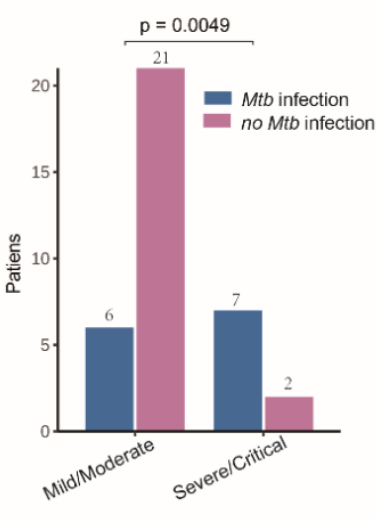

C

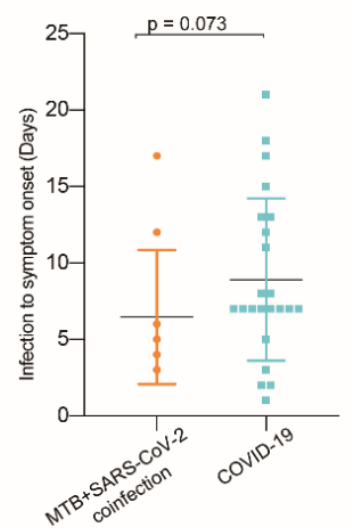

D

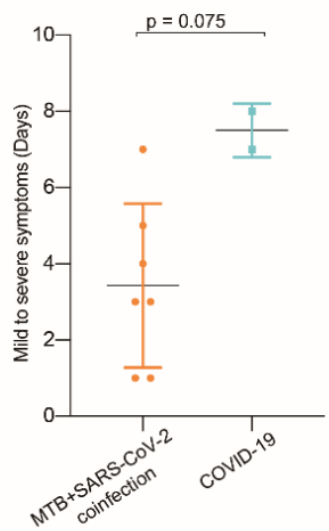

Figure 1. TB history affects susceptibility to SARS-CoV-2 and can increase disease severity.

\section{Figure 1. TB history affects susceptibility to SARS-CoV-2 and can increase disease severity.}

36 COVID-19 patients, 115 bacterial pneumonia patients and 62 viral pneumonia patients were tested for MTB infection using IFN- $\gamma$ release ELISPOT assays. IFN- $\gamma$ release indicated MTB infection. A. MTB infection is more common among COVID-19 patients than in those with bacterial or other viral pneumonias. B. Patients with MTB infection developed more severe COVID-19 symptoms. C. COVID-19 symptoms develop more rapidly in patients with MTB coinfection. B. COVID-19 patients with MTB infection develop severe complications more rapidly. Comparisons between groups were made using Fisher's exact test $(n<40 ; p \leq 0.05)$, or the MannWhitney test $(n>40 ; p \leq 0.05)$. 
medRxiv preprint doi: https://doi.org/10.1101/2020.03.10.20033795; this version posted March 16, 2020. The copyright holder for this preprint (which was not certified by peer review) is the author/funder, who has granted medRxiv a license to display the preprint in It is made available under a CC-BY-NC-ND 4.0 International license .

\section{Supplementary Information}

Supplementary Table 1.

Demographic characteristics of COVID-19 and bacterial or other viral pneumonia patients

\begin{tabular}{ccccc}
\hline & COVID-19 & Viral Pneumonia & Bacterial Pneumonia & $\boldsymbol{p}$-value* \\
\hline Patients & 36 & 62 & 115 & \\
Age (years) & $47 \pm 14$ & $49 \pm 14$ & $47 \pm 15$ & 0.477 \\
Gender (M/F) & $18 / 18$ & $33 / 29$ & $64 / 51$ & 0.83 \\
\hline
\end{tabular}

Data: mean \pm SD or $\mathrm{n} .{ }^{*}$ Significance of differences between groups. 